\title{
Da kunnskapen om alloimmun antistoffdanning kom til
}

\author{
Om kort tid er det 50 år siden alloim- \\ mun antistoffdanning under svanger- \\ skapet ble oppdaget: 9. juni 1960 ble \\ det klart for undertegnede og Jon Lun- \\ devall at dette var en realitet. Resulta- \\ tet ble tre år senere publisert i Nature.
}

Utgangspunktet var en undersøkelse av neonatal forblødning hos smågris i Romedal. Nesten alle i kullet til en purke ble tiltakende medtatte og døde 7-12 dager etter. Tre kadavre ble sendt til patologisk institutt ved Norges veterinærhøgskole. Ved seksjon fant man utbredte blødninger. Et slikt bilde ses ved svinepest, en kjent årsak til fryktet epizooti. Veterinærdirektøren beordret total isolasjon av gården, og jeg ble bedt om å foreta undersøkelse på stedet fordi jeg hadde kompetanse på hemostase etter å ha disputert under Paul Owren ved Rikshospitalet. Dessuten var jeg også godt kjent med Jon Lundevall som deltok i lørdagsmøtene på Tromboseinstituttet og som var god på serologi. Det skulle vise seg å være avgjørende. I løpet av noen travle timer utrustet vi oss med det nødvendigste utstyr i en varebil. Kopi av et komprimert resymé viser «utflukten» time for time.

\subsection{0:}

Tre døde grisunger til Patologen, Norges Veterinærhøyskole, fra Romedal Funn: Døde av forblødning, mistanke om svinepest

K1 1830: Avreise for undersøkelse på stedet K1 2100: Ankomst gården. Svinepest avkreftet, gården fristilt K1 2100-0500: Platetellinger, koagula- sjonstester, hemoglobinmålinger, fibrinogen, fibrinolyse, utstrakt prøvetaking Funn: Uttalt trombopeni, blødninger og grav anemi, andre undersøkelser normale

\subsection{0:}

K1 0500: Retur med blodprøver, 4 ennå levende unger, hvorav 2 moribundne K1 0630: Jessheim st. Telefon til Lundevall om serologisk undersøkelse.

K1 0730: Veterinærhøyskolen. En gris død, en innsatt Medisinsk klinikk

Kl 0800: Via Fellesslakteriet til Lundevalls laboratorium, Rikshospitalet

K1 0830: Undersøkelsene begynner Kl 1530: Lundevall kommer med resultatene: Arsaken til blødningene er plateantistoffer i morens blod på grunn av forskjell $i$ antigengruppene mellom morens og avkommets plater (iso/allo-immunisering)

Da Lundevall ble forespurt om han kunne foreta en serologisk undersøkelse, tok han straks utfordringen, bad bare om at vi også måtte skaffe blod fra et tilstrekkelig antall normale griser. Etter å ha avlevert prøvene fikk jeg sove på hans kontor etter nattens strabaser. Han kom inn etter noen timer, og jeg så på hans ansiktsuttrykk (han var en meget vennlig mann, men smilte sjelden) at han hadde en stor nyhet å fortelle: han hadde påvist et plateantistoff $\mathrm{i}$ blodet fra moren og en smågris. Purka hadde imidlertid ikke trombopeni selv om hun måtte ha utskilt antistoffet i melken.

Halldis Lie ved Medisinsk klinikk, Norges Veterinærhøgskole, ble satt på den videre forskning. Hun fant bl.a. ved å undersøke flere slike kull og 300 slaktegriser at det var to andre epitoper som kunne være årsak til iso/alloimmunisering $(1,2)$. Dette ble også først kjent for mennesket mange år etterpå. Hovedepitopen er den samme hos de to artene, HPA-1a. Lie fant at den sto for $87 \%$. Det var meningen at hun skulle disputere på temaet, men hun fikk ikke sluttført studiene fordi Institutt for rettsmedisin trengte en immunolog til farskapssaker. Vår publikasjon om dette i Nature kom derfor ikke før 1963 (3). Kort tid etter vårt tokt ble slik immunisering også konstatert hos menneske og er nå godt utforsket, også i Norge $(4,5)$.

Blødningene hos grisefostre begynner ikke før omtrent en uke postnatalt og når maksimum i løpet av to uker, mens de hos kvinner ofte starter intrauterint. Dette har sin forklaring $i$ at antistoffene må passere flere cellelag hos gris, fordi de har en placenta epitheliochoralis i motsetning til mennesket, som har en placenta haemochorialis. Avkommet får derfor storparten av antistoffene gjennom melken hos grisen. Beinmargsprøver viste at megakaryocyttene var sterkt redusert.

Forblødninger hos nyfødt gris har vært kjent fra de eldste tider, og etter publikasjonen i Nature fikk vi meddelelser fra mange land. Forekomsten hos gris er ikke veldig stor - på linje med hos mennesket kanskje - men når storparten av et kull - eller hele kullet - stryker med, er det tøft både økonomisk og følelsesmessig for oppdretteren. For ham er ikke grisen et svin. Etter at oppdretterne fikk råd om å kutte ut slike avlsdyr, er problemet praktisk talt forsvunnet i de fleste land. Slik sett er det enklere for veterinæren å gi gode råd enn for legen.

\section{Helge Stormorken}

hestormo@frisurf.no

Konvallvn. 4, 1338 Sandvika

\section{Oppgitte interessekonflikter: Ingen}

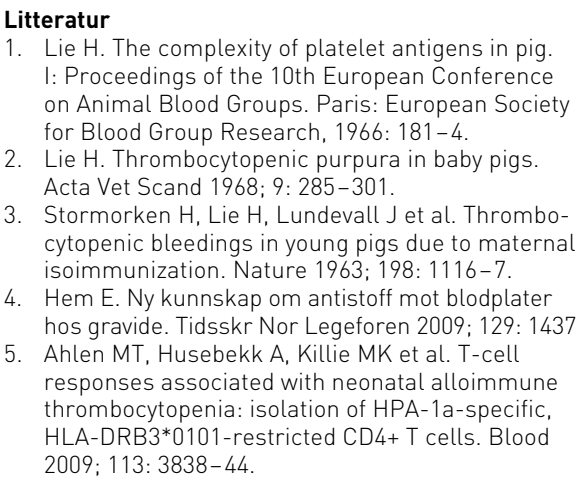

